\title{
Simple, Difficult, or Prolonged Weaning: The Most Important Factor Is the Success or Failure of the First Weaning Trial
}

A recent international consensus conference ${ }^{1}$ published in 2007 proposed to categorize ventilated patients into 3 groups, based on the difficulty and duration of the weaning process: "simple weaning" (group 1) includes patients who succeed the first weaning trial and are extubated without difficulty, "difficult weaning" (group 2) includes patients who fail the first weaning trial and require up to 3 spontaneous breathing trials or 7 days to achieve successful weaning, and "prolonged weaning" (group 3) includes patients who require more than 7 days of weaning after the first weaning trial. According to the literature, ${ }^{2-4}$ the proportion of patients in each group was estimated at $70 \%$ for simple weaning, $15 \%$ for difficult weaning, and $15 \%$ for prolonged weaning. The conference emphasized that the first weaning trial must be performed as soon as the patient meets the following criteria: resolution of disease for which the patient was intubated; cardiovascular stability with no or minimal vasopressors; no continuous sedation; and adequate oxygenation, defined as $\mathrm{P}_{\mathrm{aO}_{2}} / \mathrm{F}_{\mathrm{IO}_{2}} \geq 150 \mathrm{~mm} \mathrm{Hg}$ and $\mathrm{PEEP} \leq 8 \mathrm{~cm} \mathrm{H}_{2} \mathrm{O}$.

See the Original Study on Page 583

This last point is crucial and could explain the differences in failure rates of the first weaning trial reported in this issue of Respiratory CARE by Tonnelier et al. ${ }^{5}$ In earlier studies, ${ }^{2-4}$ a weaning trial was performed when $\mathrm{F}_{\mathrm{IO}_{2}}$ was $\leq 40 \%$, PEEP $\leq 5 \mathrm{~cm} \mathrm{H}_{2} \mathrm{O}, \mathrm{P}_{\mathrm{aO}_{2}} / \mathrm{F}_{\mathrm{IO}_{2}}>200 \mathrm{~mm} \mathrm{Hg}$, and after the success of respiratory physiology criteria, with a rapid shallow breathing index $<105$ breaths $/ \mathrm{min} / \mathrm{L}$, and maximum inspiratory pressure $>-20 \mathrm{~cm} \mathrm{H}_{2} \mathrm{O}$. In more recent studies, ${ }^{6,7}$ patients were screened earlier to pass a weaning trial $\left(\mathrm{F}_{\mathrm{IO}_{2}} \leq 50 \%\right.$ with PEEP up to $\left.8 \mathrm{~cm} \mathrm{H}_{2} \mathrm{O}\right)$ and could be extubated with a $\mathrm{P}_{\mathrm{aO}_{2}} / \mathrm{F}_{\mathrm{IO}_{2}}<200 \mathrm{~mm} \mathrm{Hg}$ without added respiratory physiology criteria that are unnecessary and may in fact delay extubation. ${ }^{8}$ In earlier studies the failure rate of the first weaning trial was not $30 \%$, as expected, but $40-50 \%$ of patients. ${ }^{6,7}$ Tonnelier et $\mathrm{al}^{5}$ report their experience over a 1 -year period with an early weaning strategy modeled on the recent recommendations. ${ }^{1}$ The first-weaning-trial failure rate was $46 \%$, but over $70 \%$ of the patients were ventilated more than 48 hours. $^{5}$ Another fundamental result is that mortality was higher in the patients with prolonged weaning, but not in the patients with difficult weaning, as compared to the simple weaning patients.

The success or failure of the first weaning trial distinguishes the simple weaning group from the difficult and prolonged weaning groups. After failure of the first weaning trial the main goal is to hasten weaning to prevent difficult weaning from becoming prolonged weaning. The success obviously depends on the patient, and most patients in the prolonged weaning group have neuromuscular or chronic respiratory disease, but success also depends on the treatment. In 1988, Lemaire et al clearly demonstrated the occurrence of cardiopulmonary edema as the cause of respiratory distress shortly after the beginning of a spontaneous breathing trial. ${ }^{9}$ The cardiac origin is probably one of the most common causes of weaning failure, due to systolic or diastolic left-ventricular dysfunction or to an ischemic mitral regurgitation. It should be diagnosed by all means, because it can be effectively treated with diuretics and/or vasodilators, and sometimes even by coronary angioplasty in cardiac ischemia. Recently, several studies found benefit from brain natriuretic peptide ${ }^{10-12}$ or echocardiography ${ }^{13,14}$ to unmask the cardiac origin of weaning failure.

However, the increase in left-ventricular filling pressure during the transition from mechanical ventilation to spontaneous ventilation depends on the type of weaning trial. The weaning trial is generally performed either with a T-piece and simply disconnecting the patient from the ventilator, or with a low level of pressure support, but in all cases the trial must be done without PEEP, which could mask cardiac dysfunction. ${ }^{15}$ The main objective of the weaning process in simple weaning is to detect weaning readiness as early as possible, which is best achieved with a systematic approach. A pressure-support trial is easy to implement into a protocol because it is not necessary to disconnect the patient from the ventilator, and respiratory rate and tidal volume are continuously monitored by the ventilator. In addition, the failure rate is lower with pressure support than with T-piece, ${ }^{15-17}$ due to lower respiratory muscle effort during pressure support, ${ }^{15}$ which may hasten weaning. However, the mortality of patients who fail extubation is particularly high $(40-50 \%),{ }^{18}$ and the more difficult T-piece test may reduce the re-intubation rate. Tonnelier et al found a higher rate of extubation failure in the difficult and prolonged weaning patients than 
in the simple weaning patients, ${ }^{5}$ and that result should encourage a prolonged T-piece trial, in order to avoid re-intubation in difficult-to-wean patients.

After failure of the first weaning trial, most patients are ventilated with pressure-support ventilation. ${ }^{19}$ Frequent patient-ventilator asynchrony is a risk in prolonged mechanical ventilation, ${ }^{20}$ and altered sleep quality by numerous central apneas $^{21}$ and ineffective efforts. ${ }^{22}$ An excessive ventilation delivering large tidal volume and long insufflation time is the main contributing factor to these asynchronies. ${ }^{23}$ A key objective is to optimize ventilator settings that could improve sleep quality and maybe shorten weaning duration.

The study by Tonnelier et $\mathrm{al}^{5}$ is important because it allows us to update the data on weaning since the international conference. ${ }^{1}$ Using a protocol of early weaning, the failure rate of the first weaning trial is nearly $50 \%$ of the ventilated patients in the intensive care unit (excluding drug intoxication and uncomplicated postoperative patients), and more than two thirds of the patients were ventilated more than 2 days. Tonnelier et al found a high risk of re-intubation in difficult-towean patients, and high mortality when weaning duration exceeded one week. This study highlights that failure of the first weaning trial is a warning signal, and it is necessary to initiate new research to determine the optimal treatment.

Arnaud W Thille MD PhD

Réanimation Médicale Hôpital Henri Mondor Créteil, France

\section{REFERENCES}

1. Boles JM, Bion J, Connors A, Herridge M, Marsh B, Melot C, et al. Weaning from mechanical ventilation. Eur Respir J 2007;29(5):10331056.

2. Brochard L, Rauss A, Benito S, Conti G, Mancebo J, Rekik N, et al. Comparison of three methods of gradual withdrawal from ventilatory support during weaning from mechanical ventilation. Am J Respir Crit Care Med 1994;150(4):896-903.

3. Esteban A, Frutos F, Tobin MJ, Alia I, Solsona JF, Valverdu I, et al. A comparison of four methods of weaning patients from mechanical ventilation. N Engl J Med 1995;332(6):345-350.

4. Vallverdu I, Calaf N, Subirana M, Net A, Benito S, Mancebo J. Clinical characteristics, respiratory functional parameters, and outcome of a two-hour T-piece trial in patients weaning from mechanical ventilation. Am J Respir Crit Care Med 1998;158(6):1855-1862.

5. Tonnelier A, Tonnelier JM, Nowak E, Gut-Gobert C, Prat G, Renault $\mathrm{A}$, et al. Clinical relevance of classification according to weaning difficulty. Respir Care 2011;56(5):583-590.

The author has disclosed no conflicts of interest.

Correspondence: Arnaud W Thille, Réanimation Médicale, Hôpital Henri Mondor, 51 Avenue du Maréchal de Lattre de Tassigny, 94010 Créteil, France. E-mail: arnaud.thille@hmn.aphp.fr.

DOI: $10.4187 /$ respcare.01317
6. Girard TD, Kress JP, Fuchs BD, Thomason JW, Schweickert WD, Pun BT, et al. Efficacy and safety of a paired sedation and ventilator weaning protocol for mechanically ventilated patients in intensive care (Awakening and Breathing Controlled trial): a randomised controlled trial. Lancet 2008;371(9607):126-134.

7. Funk GC, Anders S, Breyer MK, Burghuber OC, Edelmann G, Heindl $\mathrm{W}$, et al. Incidence and outcome of weaning from mechanical ventilation according to new categories. Eur Respir J 2010;35(1):88-94.

8. Tanios MA, Nevins ML, Hendra KP, Cardinal P, Allan JE, Naumova $\mathrm{EN}$, et al. A randomized, controlled trial of the role of weaning predictors in clinical decision making. Crit Care Med 2006;34(10):2530-2535.

9. Lemaire F, Teboul JL, Cinotti L, Giotto G, Abrouk F, Steg G, et al. Acute left ventricular dysfunction during unsuccessful weaning from mechanical ventilation. Anesthesiology 1988;69(2):171-179.

10. Mekontso-Dessap A, de Prost N, Girou E, Braconnier F, Lemaire F, Brun-Buisson $\mathrm{C}$, et al. B-type natriuretic peptide and weaning from mechanical ventilation. Intensive Care Med 2006;32(10):1529-1536.

11. Grasso S, Leone A, De Michele M, Anaclerio R, Cafarelli A, Ancona $\mathrm{G}$, et al. Use of N-terminal pro-brain natriuretic peptide to detect acute cardiac dysfunction during weaning failure in difficult-to-wean patients with chronic obstructive pulmonary disease. Crit Care Med 2007;35(1):96-105.

12. Zapata L, Vera P, Roglan A, Gich I, Ordonez-Llanos J, Betbese AJ. B-type natriuretic peptides for prediction and diagnosis of weaning failure from cardiac origin. Intensive Care Med (2011, In Press).

13. Lamia B, Maizel J, Ochagavia A, Chemla D, Osman D, Richard C, et al. Echocardiographic diagnosis of pulmonary artery occlusion pressure elevation during weaning from mechanical ventilation. Crit Care Med 2009;37(5):1696-1701.

14. Ait-Oufella H, Tharaux PL, Baudel JL, Vandermeersch S, Meyer P, Tonnellier $\mathrm{M}$, et al. Variation in natriuretic peptides and mitral flow indexes during successful ventilatory weaning: a preliminary study. Intensive Care Med 2007;33(7):1183-1186.

15. Cabello B, Thille AW, Roche-Campo F, Brochard L, Gomez FJ, Mancebo J. Physiological comparison of three spontaneous breathing trials in difficult-to-wean patients. Intensive Care Med 2010; 36(7):1171-1179.

16. Esteban A, Alia I, Gordo F, Fernandez R, Solsona JF, Vallverdu I, et al. Extubation outcome after spontaneous breathing trials with $\mathrm{T}$ tube or pressure support ventilation. The Spanish Lung Failure Collaborative Group Am J Respir Crit Care Med 1997;156:459-465.

17. Ezingeard E, Diconne E, Guyomarc'h S, Venet C, Page D, Gery P, et al. Weaning from mechanical ventilation with pressure support in patients failing a T-tube trial of spontaneous breathing. Intensive Care Med 2006;32(1):165-169.

18. Epstein SK, Ciubotaru RL, Wong JB. Effect of failed extubation on the outcome of mechanical ventilation. Chest 1997;112(1):186-192.

19. Esteban A, Ferguson ND, Meade MO, Frutos-Vivar F, Apezteguia C, Brochard L, et al. Evolution of mechanical ventilation in response to clinical research. Am J Respir Crit Care Med 2008;177(2):170-177.

20. Thille AW, Rodriguez P, Cabello B, Lellouche F, Brochard L. Patient-ventilator asynchrony during assisted mechanical ventilation. Intensive Care Med 2006;32(10):1515-1522.

21. Parthasarathy S, Tobin MJ. Effect of ventilator mode on sleep quality in critically ill patients. Am J Respir Crit Care Med 2002;166(11): 1423-1429.

22. Fanfulla F, Delmastro M, Berardinelli A, Lupo ND, Nava S. Effects of different ventilator settings on sleep and inspiratory effort in patients with neuromuscular disease. Am J Respir Crit Care Med 2005; 172(5):619-624.

23. Thille AW, Cabello B, Galia F, Lyazidi A, Brochard L. Reduction of patient-ventilator asynchrony by reducing tidal volume during pressure-support ventilation. Intensive Care Med 2008;34(8):1477-1486. 